\title{
THE INFLUENCE OF FEED RESTRICTION AND SUBSEQUENT RE-FEEDING ON GONADOTROPHIN SECRETION AND SERUM TESTOSTERONE LEVELS IN MALE RATS
}

\author{
B. E. HOWLAND \\ Department of Oral Biology, University of Manitoba, \\ Winnipeg, Manitoba R3E 0W3, Canada
}

(Received 29th October 1974)

\begin{abstract}
Summary. Male rats at 3 months were fully fed or were restricted to $50 \%$ of normal feed intake for 10 or 20 days. Underfeeding for either period resulted in reduced $(P<0.05)$ body weight and pituitary weight but did not affect testicular weight. Underfeeding for 20 days resulted in reduced $(P<0.05)$ weights of the seminal vesicles and ventral prostate. The serum concentration of LH was depressed $(P<0.05)$ after 10 days of underfeeding and the pituitary concentration of $\mathrm{LH}$ was elevated $(P<0.05)$ after 20 days of underfeeding. Neither serum nor pituitary concentration of FSH was influenced by feed level. Serum testosterone concentration was reduced in rats underfed for 20 days.

In a second study, 2-month-old males were fully fed, underfed (15 days) or underfed and then re-fed (full feed) for 1, 2, 3 or 7 days. Underfeeding produced effects similar to those noted in the first experiment. Re-feeding of underfed rats resulted in body and ventral prostate weights returning to levels similar to those of fully fed controls by Day 7. The serum level of FSH was elevated $(P<0 \cdot 05)$ above the control level on Days 1, 3 and 7 of re-feeding, while the serum level of LH appeared to return to the control level. Serum testosterone level rebounded and exceeded $(P<0.05)$ the control level on Days 1 and 2 of re-feeding.
\end{abstract}

\section{INTRODUCTION}

The detrimental effect of underfeeding on reproductive processes in the male rat are well documented. Restricted feed intake has been reported to reduce the weight of accessory sex glands (Moore \& Samuels, 1931; Mulinos \& Pomerantz, 1941; Quimby, 1948; Berliner \& Ellis, 1965; Grewal et al., 1971). Recent work by Grewal $e t a l$. (1971) has shown that the reduced accessory gland weights are associated with reduced serum levels of testosterone. Although underfeeding appears to have its greatest effect on the steroid-secreting activity of the testes (Berliner \& Ellis, 1965; Grewal et al., 1971), reduced testicular weights have also been reported (Mulinos \& Pomerantz, 1941; Berliner \& Ellis, 1965; 
Grewal et al., 1971). The process of spermatogenesis, however, appears to be little affected by underfeeding since Grewal et al. (1971) have shown that $50 \%$ feed restriction for 23 weeks had no significant effect on epididymal or testicular sperm concentrations.

The fact that the defects resulting from underfeeding can be corrected by administering gonadotrophins (Moore \& Samuels, 1931; Mulinos \& Pomerantz, 1941) has provided evidence that the basic problem in underfed rats is one of pituitary failure to secrete adequate amounts of gonadotrophins. Reduced serum levels of LH have been reported in underfed female rats (Howland, 1971, 1972; Gombe et al., 1973), but serum levels of FSH were not affected by underfeeding (Howland, 1971). Short periods of complete starvation, however, result in significantly reduced serum levels of both gonadotrophins (Howland \& Skinner, 1973; Howland et al., 1974) in male rats.

The present study was conducted to determine the effects of reduced feed intake and of subsequent re-feeding on serum and pituitary levels of gonadotrophins and on serum testosterone levels in male rats.

\section{MATERIALS AND METHODS}

Sprague--Dawley rats from our own colony were used in this study. During the experimental periods, the rats were kept in individual cages in a light- $(12 \mathrm{hr}$ light $/ 12 \mathrm{hr}$ dark) and temperature- $\left(74 \pm 1^{\circ} \mathrm{F}\right)$ controlled room. The animals were fed Purina Lab Chow freely or were restricted to $50 \%$ of the average daily feed consumption determined for all rats in the experiment during a 3-day pre-experimental period (underfed). All animals had free access to tap water.

All rats were killed in the morning by decapitation. Trunk blood was collected and allowed to clot. The serum was frozen until hormone assays were conducted. Pituitaries were removed, weighed and frozen. Testes and accessory sex glands were removed and weighed.

In the first experiment, three groups of 3-month-old rats were studied. The rats in one group served as fully fed controls, those in a second group were underfed for 10 days and those in the third group were underfed for 20 days. Half of the rats in the control group were killed at the same time as the rats in each of the underfed groups.

In a second study, six groups of 2-month-old animals were studied. The rats in five groups were underfed for 15 days and the remaining group of rats served as fully fed controls. The rats in one underfed group were killed after 15 days of treatment and the remaining groups were then allowed free access to food (re-fed). Subsequently, rats were killed after 1, 2, 3 and 7 days of refeeding. Two or three control rats were killed at the same time as those in each of the other groups.

The concentration of LH in pituitary homogenates and sera was determined by the ovine-ovine radioimmunoassay described by Niswender et al. (1968). A similar double-antibody radioimmunoassay, distributed by the National Institute of Arthritis and Metabolic Diseases, NIH, was used to measure FSH concentration. Data on LH and FSH were expressed in terms of NIAMD-ratLH-RP1 and NIAMD rat FSH-RP1, respectively. In each experiment, all 
serum samples were assayed for gonadotrophins in a single assay. The sensitivity of the LH method was $5 \mathrm{ng} / \mathrm{ml}$ and for the FSH method was $100 \mathrm{ng} / \mathrm{ml}$ when $200 \mu \mathrm{l}$ serum were used. These levels of sensitivity corresponded to approximately $90 \%$ binding of labelled hormone when the binding in tubes containing no unlabelled hormone was expressed as $100 \%$. When $\mathrm{LH}$ values below the sensitivity of the method were encountered, the values were estimated from the standard curve rather than assigning an arbitrary value. The within-assay variance (Rodbard, 1971) for the LH method was 2.44 when calculated from 61 duplicate determinations of unknowns ranging from 10 to $40 \mathrm{ng} / \mathrm{ml}$. For the FSH method, the within-assay variance was 961 when calculated from 62 duplicate determinations of unknowns with a range of 220 to $610 \mathrm{ng} / \mathrm{ml}$. The concentrations of LH and FSH in a pool of rat serum were each determined in five separate assays. The mean $\mathrm{LH}$ concentration was $12.4 \mathrm{ng} / \mathrm{ml}$ and the coefficient of variation was $12.7 \%$, and for the FSH method the mean was $544 \mathrm{ng} / \mathrm{ml}$ and the coefficient of variation was $10.4 \%$.

Serum levels of testosterone were determined by radioimmunoassay (Sanford et al., 1974). Two or more assays were required to determine testosterone levels for each of the experiments. There were approximately equal numbers of samples from each treatment group in an assay.

The data were examined by analysis of variance and Duncan's multiple range test (Steele \& Torrie, 1960). Two testosterone values in the second experiment, that were four to five times higher than the mean of the other values in the groups where they occurred, were not considered to be representative and were not included in the means.

\section{RESULTS}

The data obtained in the first experiment are summarized in Table 1. Restricted feeding for 10 or 20 days reduced $(P<0.05)$ body weights and pituitary weights but did not affect testicular weights. Underfeeding for 20 days reduced $(P<0 \cdot 05)$

Table 1. Effect of $50 \%$ feed restriction for 10 or 20 days on body and organ weights and on gonadotrophin levels in male rats

\begin{tabular}{|c|c|c|c|}
\hline \multirow{2}{*}{ Characteristic } & \multicolumn{3}{|c|}{ Duration of feed restriction (days) } \\
\hline & 0 & 10 & 20 \\
\hline $\begin{array}{l}\text { No. of rats } \\
\text { Body wt }(\mathrm{g}) \\
\text { Pituitary wt }(\mathrm{mg}) \\
\text { Testicular wt }(\mathrm{g}) \\
\text { Ventral prostate wt }(\mathrm{mg}) \\
\text { Seminal vesicle wt }(\mathrm{mg}) \\
\text { Pituitary LH conc. }(\mu \mathrm{g} / \mathrm{mg}) \\
\text { Pituitary FSH conc. }(\mu \mathrm{g} / \mathrm{mg}) \\
\text { Serum LH conc. }(\mathrm{ng} / \mathrm{ml}) \\
\text { Serum FSH conc. }(\mathrm{ng} / \mathrm{ml}) \\
\text { Serum testosterone conc. }(\mathrm{ng} / \mathrm{ml})\end{array}$ & $\begin{array}{c}12 \\
478 \pm 11^{\mathrm{a}} \\
12 \cdot 7 \pm 0 \cdot 5^{\mathrm{a}} \\
3 \cdot 90 \pm 0 \cdot 13 \\
593 \pm 34^{\mathrm{a}} \\
420 \pm 12^{\mathrm{a}} \\
24 \cdot 0 \pm 1 \cdot 8^{\mathrm{a}} \\
8 \cdot 1 \pm 0 \cdot 3 \\
31 \cdot 9 \pm 3 \cdot 0^{\mathrm{a}} \\
527 \pm 31 \\
2 \cdot 56 \pm 0 \cdot 35^{\mathrm{a}}\end{array}$ & $\begin{array}{l}10 \\
376 \pm 10^{\mathrm{b}} \\
10 \cdot 4 \pm 0 \cdot 4^{\mathrm{b}} \\
3 \cdot 82 \pm 0 \cdot 10 \\
515 \pm 37^{\mathrm{a}} \\
390 \pm 16^{\mathrm{a}} \\
26 \cdot 8 \pm 1 \cdot 6^{\mathrm{a}, \mathrm{b}} \\
10 \cdot 0 \pm 0 \cdot 6 \\
21 \cdot 3 \pm 4 \cdot 2^{\mathrm{b}} \\
504 \pm 19 \\
2 \cdot 25 \pm 0 \cdot 18^{\mathrm{a}, \mathrm{b}}\end{array}$ & $\begin{array}{c}10 \\
351 \pm 9^{\mathrm{b}} \\
9 \cdot 4 \pm 0 \cdot 5^{\mathrm{b}} \\
3 \cdot 70 \pm 0 \cdot 05 \\
319 \pm 34^{\mathrm{b}} \\
280 \pm 11^{\mathrm{b}} \\
29 \cdot 9 \pm 1 \cdot 9^{\mathrm{b}} \\
9 \cdot 0 \pm 0 \cdot 7 \\
22 \cdot 8 \pm 2 \cdot 5^{\mathrm{a}, \mathrm{b}} \\
479 \pm 56 \\
1 \cdot 49 \pm 0 \cdot 22^{\mathrm{b}}\end{array}$ \\
\hline
\end{tabular}

Values expressed Mean \pm S.E.M.

a,b Means not bearing identical superscripts differ significantly $(P<0.05)$. 


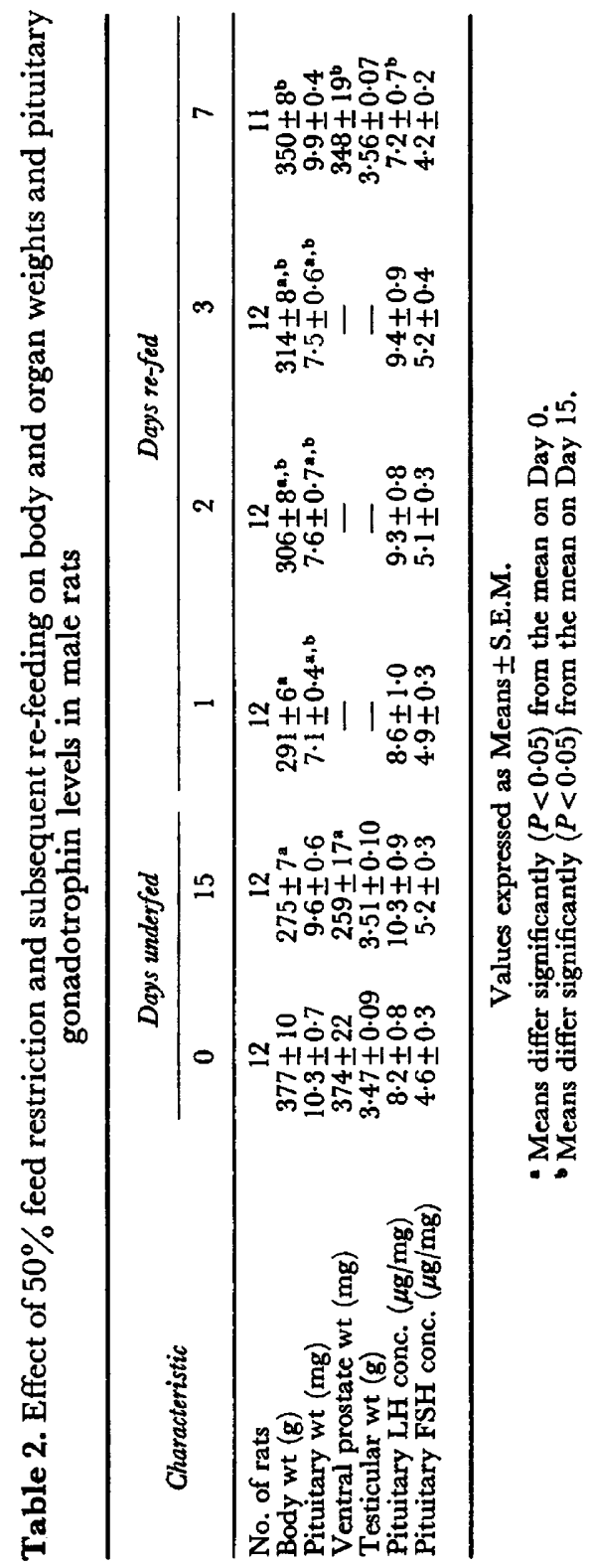


the weights of the accessory sex glands below the control values. The pituitary LH concentration in rats underfed 20 days was higher $(P<0.05)$ than that in controls, but the pituitary FSH concentration was not significantly affected by treatment. The serum levels of LH were lower in underfed than in fully fed rats but the difference was significant only in the 10-day group. The serum level of FSH did not differ among treatment groups. The serum testosterone concentration was depressed $(P<0.05)$ after 20 days of underfeeding.

The body and organ weights and pituitary gonadotrophin levels observed in the second experiment are shown in Table 2. The body weight was reduced $(P<0.05)$ in underfed rats and was increased $(P<0.05)$ again in rats that had been re-fed for only 2 days. Although pituitary weight was not significantly reduced in the underfed rats, those that had been underfed and then re-fed for 1,2 or 3 days had lower $(P<0.05)$ pituitary weights than did fully fed controls.

The effect of underfeeding on ventral prostate and testicular weights was similar to that noted in the first experiment. The reduced ventral prostate weights of underfed rats returned to values that were not significantly different

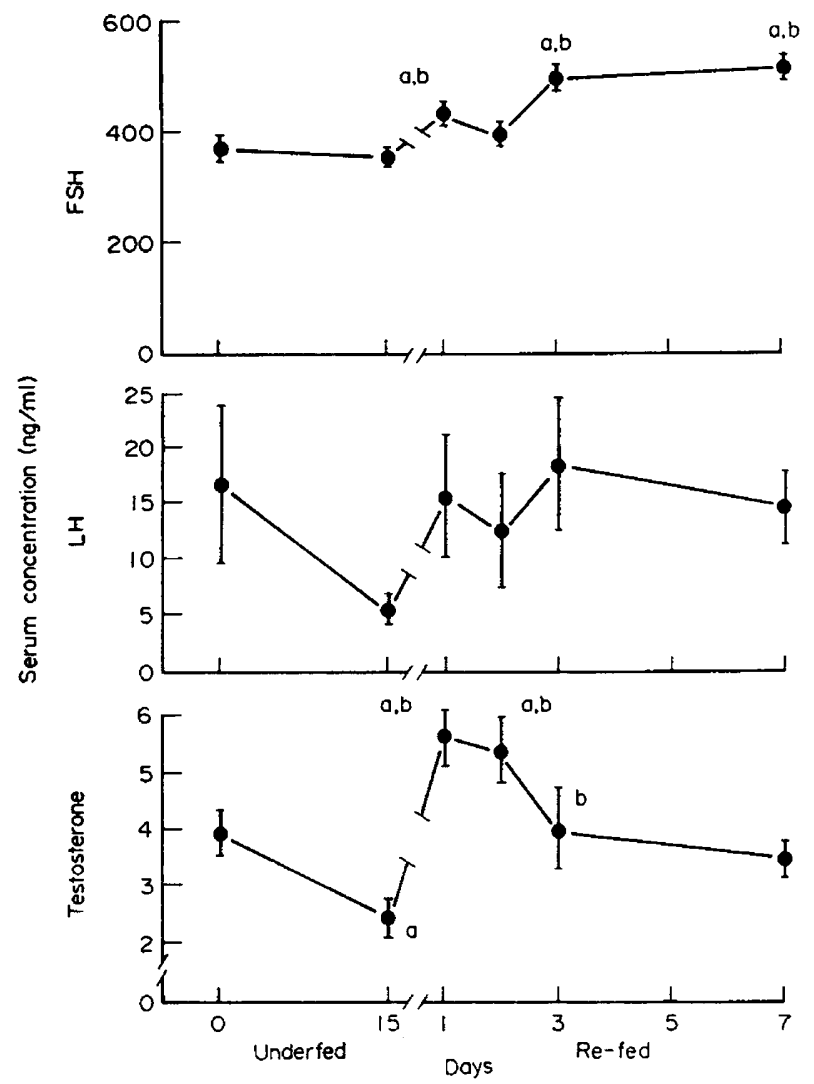

TEXT-FIG. 1. Serum levels of FSH, $\mathrm{LH}$ and testosterone after 0 or 15 days of underfeeding and $1,2,3$ or 7 days of subsequent re-feeding of male rats. The vertical bars indicate S.E.M. Means indicated by (a) differ $(P<0.05)$ from the mean on Day 0 ; means indicated by (b) differ $(P<0 \cdot 05)$ from the mean on Day 15. 
from control values by Day 7 of re-feeding. The pituitary LH concentration appeared to be elevated in underfed rats but the difference was not significant. By Day 7 of re-feeding, however, the pituitary concentration of LH was lower $(P<0.05)$ than that in underfed rats. Pituitary FSH concentration was not significantly affected by treatment.

The effect of underfeeding and re-feeding on serum levels of FSH, LH and testosterone are shown in Text-fig. 1. The serum levels of FSH were not depressed by underfeeding but did increase $(P<0.05)$ when underfed animals were re-fed. The serum levels of $\mathrm{LH}$ appeared to drop in underfed rats and then promptly return to control levels when the rats were re-fed Due to the unusually large rat-to-rat variation in $\mathrm{LH}$ levels encountered in this experiment, the changes were not statistically significant. As noted in the first experiment, underfeeding resulted in a drop $(P<0.05)$ in serum testosterone levels. After 1 day of re-feeding, the testosterone levels had rebounded to levels higher than those of the fully fed controls. The levels remained elevated on Day 2 of refeeding and then returned to levels similar to those of control rats.

\section{DISCUSSION}

Although the magnitude of the effect of underfeeding in the two experiments of this study differed for some characteristics, the direction of change was consistent. In general, it appeared that underfeeding for 10 to 20 days resulted in reduced body, pituitary and accessory sex gland weights but did not significantly alter testicular weights. Longer periods of underfeeding, however, have been shown to reduce testicular weights (Grewal et al., 1971). The reduction in accessory sex gland weights that occurs in underfed rats appears to be due to the reduced serum levels of testosterone. The reduced testosterone levels observed in the underfed rats in this study confirm the results reported by Grewal et al. (1971).

The concentration of gonadotrophins in the pituitaries in the second experiment was considerably lower than that observed in the first experiment. This discrepancy is a result of a difference in the method of handling the glands in the two experiments. In the second experiment (for reasons unrelated to this study), each gland was weighed, placed in $0.2 \mathrm{ml}$ distilled water and was then removed $1 \mathrm{hr}$ later, blotted, weighed and homogenized. The hormone concentrations appear low because of leaching of hormone from the glands and the fact that concentrations were expressed in terms of the second (somewhat larger) weight. It was assumed that treatment group comparisons were not affected.

The results of both experiments suggest that underfeeding tends to result in an increase in the pituitary concentration of LH but not of FSH. This change is consistent with the hypothesis that underfeeding impairs release mechanisms for $\mathrm{LH}$ although the rate of hormone synthesis is probably also reduced, but perhaps later or to a lesser extent. Underfeeding, of the duration imposed in this study, does not appear to affect FSH secretion. Underfeeding of female rats does not affect serum levels of FSH but leads to elevated pituitary levels of the hormone (Howland, 1971). Srebnik \& Nelson (1964) have reported that underfeeding in female rats results in an elevated pituitary content of gonadotrophins, 
but the same treatment in males produces a moderate decrease in hormone content. Since the bioassay endpoint of Srebnik \& Nelson was the ovarian weight of hypophysectomized rats, these authors were probably measuring mostly FSH. If this assumption is correct, the results of the present study confirm the existence of a sex difference in the pituitary response to underfeeding. The lack of an effect on FSH secretion in males is consistent with the maintenance of testicular weight in the present experiment and the experiments reported by Srebnik \& Nelson (1964) and the unaltered testicular sperm concentration observed in underfed rats by Grewal et al. (1971).

It appears that in the rat, as in the bull (Mann \& Rowson, 1957; Mann et $a l .$, 1967), underfeeding affects the androgenic function of the testes much more than the spermatogenic function. The reduced androgen secretion by the testes of the underfed rat has been shown to be due to a lack of enzymes needed to convert pregnenolone and progesterone to androgens (Berliner \& Ellis, 1965). The enzyme deficiency was assumed to be due to a lack of gonadotrophin. The low LH levels observed in the present experiment support this hypothesis.

The re-feeding of previously underfed rats resulted in a significant elevation in serum levels of FSH, a return of LH levels to normal and rebound in serum testosterone to levels above that of fully fed controls. The rise in serum FSH levels was unexpected since underfeeding did not depress the levels of this hormone. It is also difficult to explain this change since it occurred simultaneously with elevated testosterone levels, but it seems possible that a period of underfeeding followed by re-feeding may have some beneficial effects on spermatogenic function. The rise in serum testosterone to levels which were significantly greater than those of fully fed controls does not appear to be explained by the changes in serum LH levels, since they only returned to control levels. It is possible that the sensitivity of the interstital cells to LH was temporarily increased. It is also possible that the availability of precursors or energy for steroid synthesis was greater than normal due to the hyperphagia that occurs after a period of underfeeding (B.E. Howland and E.A. Ibrahim, unpublished observations). Grewal et al. (1971) found elevated testosterone levels in rats that had been re-fed for 3 weeks after a 20-week restricted feeding period. Our results indicate that with shorter periods of underfeeding, the rebound in testosterone levels is short-lived but can still be demonstrated.

\section{ACKNOWLEDGMENTS}

This work was supported by grant MA 4454 from the Medical Research Council of Canada. The author is grateful to Dr G.D. Niswender, Dr L.E. Reichert, $\mathrm{Jr}$ and the National Institute of Arthritis and Metabolic Diseases, Rat Pituitary Hormone Program for supplying the gonadotrophin radioimmunoassay materials. Appreciation is extended to Miss M.I. Jack and Mr D.B. Beaton for excellent technical assistance.

\section{REFERENCES}

BerLINER, D. \& Elurs, L.G. (1965) The effects of irradiation on endocrine cells. V. A comparison between the effects of inanition and irradiation on androgen production by murine testicular tissue. Radiat. Res. 24, 572-578. 
Gombe, S., Apgar, I. \& Hansel, W. (1973) Effect of zinc deficiency and restricted food intake on plasma and pituitary LH and hypothalamic LRF in female rats. Biol. Reprod. 9, 415-419.

Grewal, T., Migkelsen, D. \& Hafs, H.D. (1971) Androgen secretion and spermatogenesis in rats following semistarvation. Proc. Soc. exp. Biol. Med. 138, 723-727.

HowlaNd, B.E. (1971) Gonadotrophin levels in female rats subjected to restricted feed intake. $\mathcal{F}$. Reprod. Fert. 27, 467-470.

Howland, B.E. (1972) Effect of restricted feed intake on LH levels in female rats. 7. Anim. Sci. 34, $445-447$.

Howland, B.E. \& SkinNer, K.R. (1973) Effect of starvation on gonadotropin secretion in intact and castrated male rats. Can. F. Physiol. Pharmacol. 51, 759-762.

Howland, B.E., Beaton, D.B. \& JAGK, M.I. (1974) Changes in serum levels of gonadotropins and testosterone in the male rat in response to fasting, surgery and ether. Experientia 30, 12231225.

MANN, T. \& Rowson, L.E.A. (1957) A study of the relationship between nutrition and reproduction in identical twin bulls. Proc. Nutr. Soc. 16, xviii.

Mann, T., Rowson, L.E.A., Short, R.V. \& Skinner, J.D. (1967) The relationship between nutrition and androgenic activity in pubescent twin calves, and the effect of orchitis. 7 . Endocr. 38, 455-468.

Moore, G.R. \& SAmuels, L.T. (1931) The action of testes hormone in correcting changes induced in rat prostate and seminal vesicles by vitamin B or partial inanition. Am. F. Physiol. 96, 278-288.

Mulinos, M.G. \& Pomerantz, L. (1941) The reproductive organs in malnutrition. Effects of chorionic gonadotropin upon atrophic genitalia of underfed male rats. Endocrinology 29, 267-275.

Niswender, G.D., Midgley, A.R., Jr, Monroe, S.E. \& Reichert, L.E., JR (1968) Radioimmunoassay for rat luteinizing hormone with anti-ovine LH serum and ovine LH- ${ }^{13}$ I. Proc. Soc. exp. Biol. Med. 128, 807-811.

QuimBy, F.H. (1948) Organ weights of rats receiving hormone supplements during recovery from chronic starvation. Endocrinology 42, 263-272.

Rodbard, D. (1971) Statistical aspects of radioimmunoassays. In Principles of Competitive Protein-Binding Assays, pp. 204-259. Eds. W. D. Odell and W. H. Daughday. Lippincott, Philadelphia.

Sanford, L.M., Winter, J.S.D., Palmer, W.M. \& Howland, B.E. (1974) The profile of LH and testosterone secretion in the ram. Endocrinology 95, 627-631.

SRebnik, H.H. \& Nelson, M.M. (1964) The influence of diet on gonadotrophins of the anterior pituitary gland. In Proc. 6th Int. Congr. Nutr. pp. 375-386. Eds. C. F. Milis and R. Passmore. Livingstone, Edinburgh.

Steele, R.G.D. \& Torrie, J.H. (1960) Principles and Procedures of Statistics. McGraw-Hill, New York. 